\title{
Isotopic and related studies of Antarctic ice samples
}

\author{
N BHANDARI, $S \mathrm{~K}$ BHATTACHARYA, $\mathrm{V} N$ NIJAMPURKAR, \\ D SENGUPTA, V G SHAH, A K SINGHVI, P N SHUKLA, \\ $\mathrm{K}$ M SUTHAR and C P VOHRA* \\ Physical Research Laboratory, Ahmedabad 380009, India \\ * Geological Survey of India, Bhutan
}

MS received 7 December 1983; revised 25 March 1984

\begin{abstract}
The ice samples obtained from Dakshin Gangotri, Antarctica show the presence of nuclear debris, attributed mainly to French nuclear explosions. Cosmogenic ${ }^{7} \mathrm{Be}$ occurs at levels of $30 \mathrm{dpm} / \mathrm{L}$. The vertical profile of $\delta D$ in $6 \mathrm{~m}$ long drill core ranges between -130 and $-180 \%$ compared to Standard Mean Ocean Water (SMOW). No systematic change with depth is seen. Small amounts of dust obtained by filtering melt water show presence of metallic spherules. Absence of elements characteristic of meteoritic or cometary debris suggests that most of them are of volcanic or industrial origin.
\end{abstract}

Keywords. Antarctica; radioactive fallout; isotopic composition; spherules.

\section{Introduction}

Surface and drill core samples of ice were collected from Dakshin Gangotri, Antarctica by the first Indian expedition to Antarctica during January-February 1982. These samples were brought back in frozen condition to Goa and then transported to the Physical Research Laboratory. A series of scientific experiments were carried out to characterise these samples. These included measurements of radioisotopes ${ }^{210} \mathrm{~Pb}$, cosmogenic ${ }^{7} \mathrm{Be}$ and bomb produced ${ }^{137} \mathrm{Cs}$, stable isotopes $\mathrm{D} / \mathrm{H}$ and analysis of particulate matter.

\section{Sample description}

Two bulk and two shallow ice core samples were used for the present study. The bulk samples called ANB and ANC were approximately 20 and 101 of ice respectively. The two drill core samples consisted of several $20-50 \mathrm{~cm}$ sections of about $5 \mathrm{~cm}$ diameter going to 6 and $4 \mathrm{~m}$ depth respectively. One of the sections $2 / 5 / \mathrm{C}$ of core 2 is shown in figure 1, while it was being dissected for isotopic analysis. The samples from known depths were melted and analysed using standard techniques.

\section{Results and discussion}

\subsection{Natural and bomb-produced radioactivity in surface and core samples}

Measurements of ${ }^{7} \mathrm{Be}$ and ${ }^{137} \mathrm{Cs}$ in some samples have been made using gamma-ray spectroscopy with HPGe detector located in a $10 \mathrm{~cm}$ thick lead shield. The charac- 


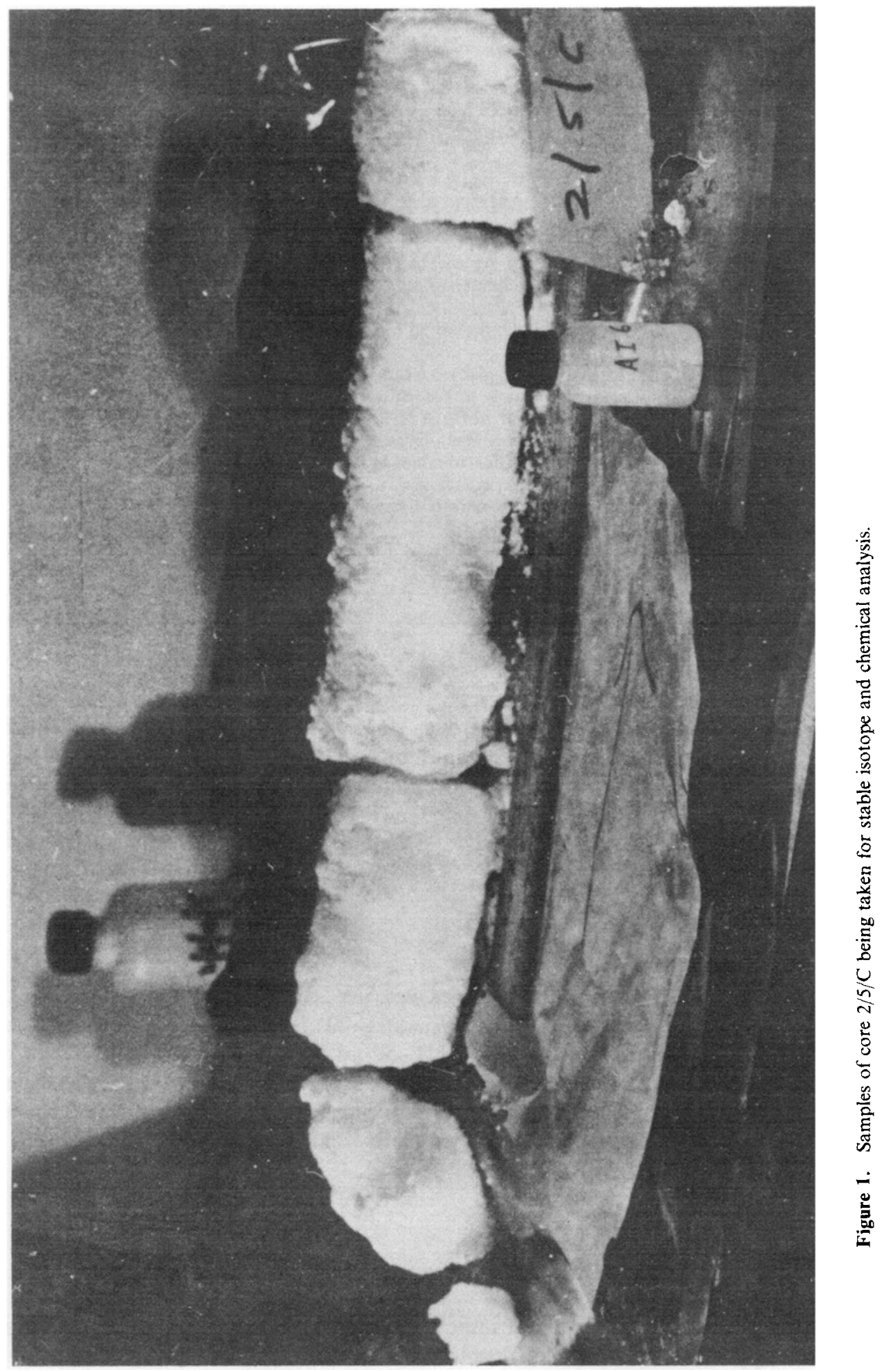


teristics of the detector background and efficiency etc were described earlier (Bhandari et al 1982). The results are summarised in table 1. Corrected for decay to the time of collection, the ${ }^{7} \mathrm{Be}$ activity roughly corresponds to $15-30 \mathrm{dpm} / \mathrm{L}$ as expected for natural fallout in Polar region. The ${ }^{137} \mathrm{Cs}$ activity measured in section $2 / 6 / \mathrm{a}$ is $0.6 \pm 0.2 \mathrm{dpm} / \mathrm{L}$.

There have been several atmospheric nuclear tests in the past few years (SIPRI 1980). The radioactive fallout due to bomb-produced activities in Antarctica samples can be attributed to the French nuclear explosions conducted at Muraroa atoll in South Pacific. The presence of ${ }^{7} \mathrm{Be}$ and ${ }^{137} \mathrm{Cs}$ suggests that the ice samples at Dakshin Gangotri are young and represent fresh precipitation. The ${ }^{210} \mathrm{~Pb}$ value of $3 \cdot 17 \mathrm{dpm} / \mathrm{L}$ is consistent with the expected fall-out level.

\subsection{Isotopic composition of water}

The isotopic composition of hydrogen has been measured in several samples from the $6 \mathrm{~m}$ core using a micromass stable isotope mass-spectrometer. Figure 2 shows $\delta D$ variations with depth. The $\delta D$ values range between $-130 \%$ (in the surface sample ANC) and $-180 \%$ in core samples. The reproducibility and the precision of the measurements are better than $2 \%$. There is no systematic change seen with depth. The $\delta D$ values are similar to those reported for King Baudouin base $\left(78^{\circ} 26^{\prime} . \mathrm{S}, 24^{\circ} 19^{\prime} \mathrm{E}\right)$ (Piccitto et al 1960) but significantly higher than that at south pole (Epstein et al 1965). The data show depletion of $\delta D$ towards poles as expected from the precipitation temperatures and suggest a mean annual surface air temperature of about $-10^{\circ} \mathrm{C}$ based on the empirical relationship established for precipitations in near Polar region (Dansgaard 1964).

Table 1. Natural and bomb produced radioactivity in surface and core samples.

\begin{tabular}{|c|c|c|c|c|c|}
\hline \multirow[t]{2}{*}{ Sample } & \multirow{2}{*}{$\begin{array}{c}\text { Sample } \\
\text { Volume } \\
\text { (L) }\end{array}$} & \multirow{2}{*}{$\begin{array}{l}\text { Date of } \\
\text { counting }\end{array}$} & ${ }^{7} \mathrm{Be}$ & ${ }^{137} \mathrm{Cs}$ & ${ }^{210} \mathrm{~Pb}$ \\
\hline & & & \multicolumn{3}{|c|}{$(\mathrm{dpm} / \mathrm{L})$} \\
\hline ANB-3 & $7 \cdot 2$ & 13.3 .82 & $7 \pm 0.4$ & $0-06 \pm 0-03$ & - \\
\hline ANC & $4 \cdot 5$ & 23.5 .82 & $7 \cdot 6 \pm 2 \cdot 1$ & $0.8 \pm 0.2$ & - \\
\hline $2 / 6 / a$ & 0.91 & 15.3 .82 & - & $0.6 \pm 0.2$ & 一 \\
\hline $2 / 1 / b$ & 0.485 & 7.3 .83 & - & - & $\begin{array}{r}3.17 \\
\pm 0.36\end{array}$ \\
\hline
\end{tabular}

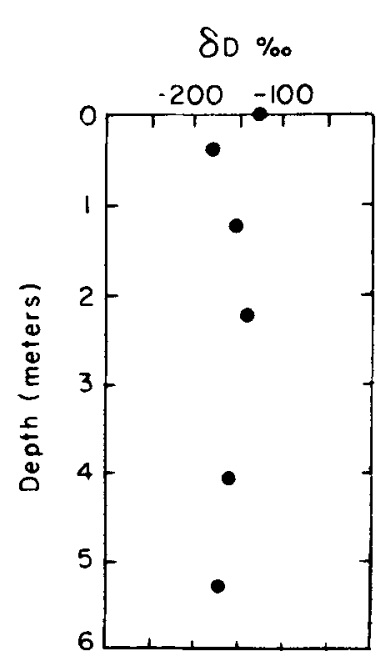

Figure 2. $\delta D$ concentration with depth. 


\subsection{Chemical analysis of spherules}

The melt water ( $4.5 \mathrm{l})$ obtained from bulk ice sample ANC was filtered on millipore papers in a clean room and the particles were examined under a microscope. A core sample from sample $2 / 6$ was also similarly studied. The dust showed presence of some spherules which were quantitatively separated. The majority of the spherules obtained were smooth, black, shining and perfectly spherical in shape. Some of these had less lustre and rough or pitted surface. These spherules might be from any one of the three sources viz. cosmic, volcanic and industrial (Bhandari et al 1968; King and Wagstaff 1981; Wagstaff and King 1981; Blanchard et al 1980). Some of these spherules are hollow suggesting volcanic origin. The size frequency distribution is shown in figure 3. Most of the spherules lie in the range of 40 to $100 \mu \mathrm{m}$. Some of the spherules were mounted on Al-disc using double sided tape and coated with Au-Pd for SEM studies. Surface structure of a spherule is shown in figure 4 . The chemical analysis of the spherules obtained by a Kevex Si(li) detector attached to the SEM is given in table 2 . Absence of Ni which is characteristic of meteoritich iron in any of the spherules studied indicates that none may be definitely extra-terrestrial in origin. However, some authors (King and Wagstaff 1981) consider $\mathrm{FeS}$ and $\mathrm{FeO}$ spheres as extra-terrestrial. In such a case five of the 35 spherules which are compositionally magnetite could be assigned to extra-terrestrial category. Other spherules with Si-Mn-Fe composition might also be extra-terrestrial in origin. Some other particles having compositions Si-Al-S and Si-STi-Cr-Fe seem to be volcanic in origin. Compositions of most of the other spherules having varying compositions and combinations of $\mathrm{Al}-\mathrm{Si}-\mathrm{Ca}-\mathrm{Ti}-\mathrm{Mn}-\mathrm{Fe}-\mathrm{K}-\mathrm{Mg}$ also indicate volcanic origin or these might be terrestrial contaminants.

The identification and collection of interplanetary dust is an important problem and

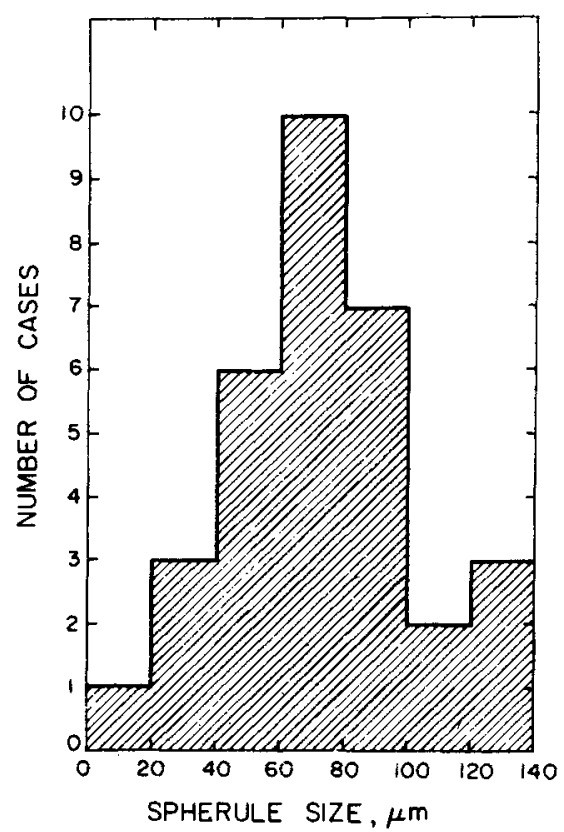

Figure 3. Size frequency distribution of spherules. 


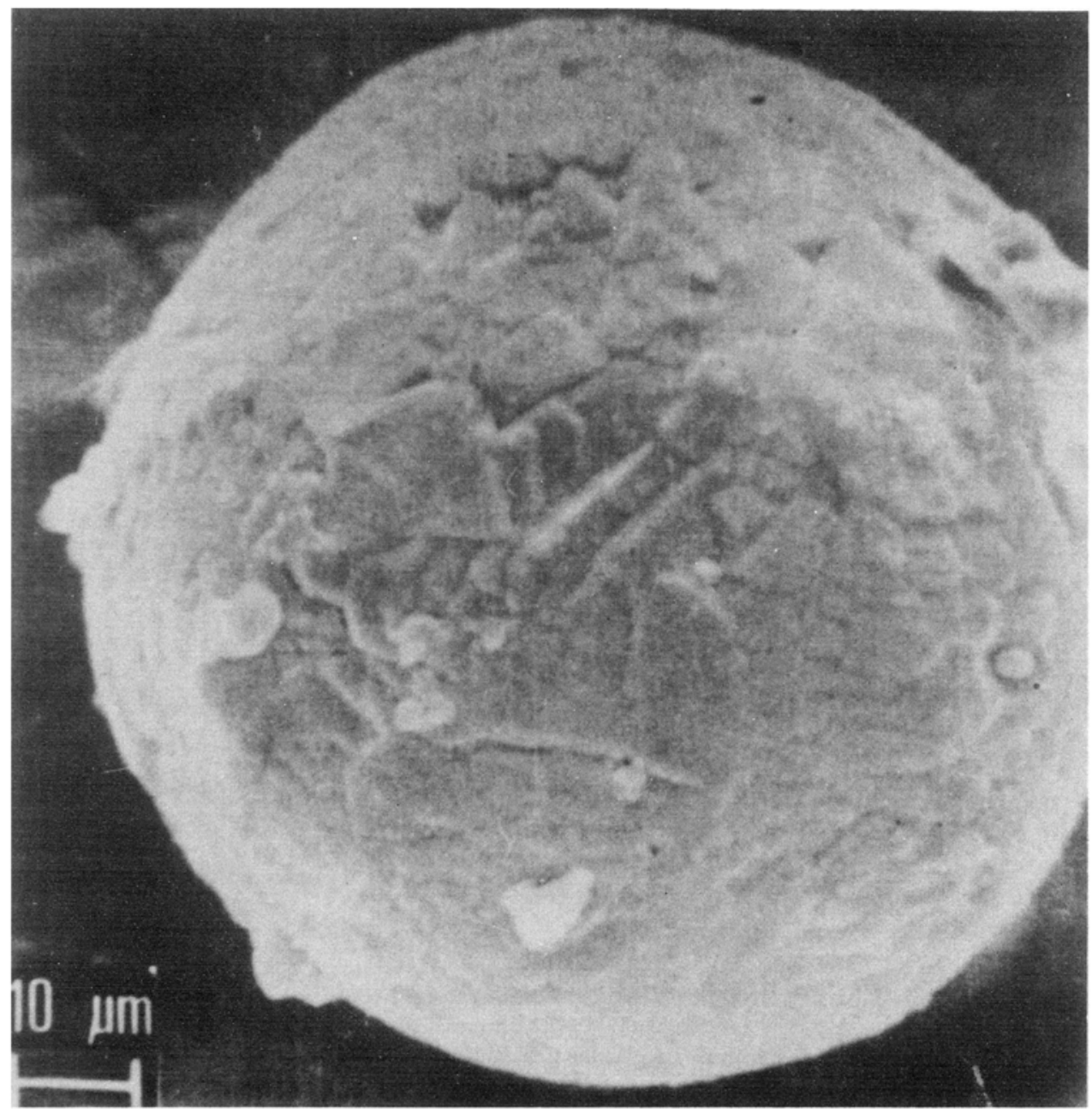

Figure 4. SEM microphotograph of a spherule type 2 from the bulk ice sample showing surface structures.

considerable efforts have been made to collect the dust in the stratosphere by balloons (Bhandari et al 1968), aircrafts (Blanchard et al 1980) etc. Antarctic ice presents a simple opportunity of collecting the interplanetary dust since the terrestrial contamination is minimum there (King and Wagstaff 1981). Although the present results are not unambiguous, if a clean collection is carefully planned, significant amounts of interplanetary dust can be collected from Antarctic ice.

\section{Acknowledgements}

The authors are grateful to the members of the first Indian Antarctic Expedition for obtaining samples for this work. 
Table 2. Chemical type of spherules and their frequency.

\begin{tabular}{|c|c|c|}
\hline Type & Elements present & $\begin{array}{c}\text { Number of } \\
\text { spherules }\end{array}$ \\
\hline 1 & $\mathbf{S i}$ & 1 \\
\hline 2 & $\mathrm{Fe}$ & 5 \\
\hline 3 & $\mathrm{Si}, \mathrm{Fe}(++)$ & 2 \\
\hline 4 & $\mathrm{Mn}, \mathrm{Fe}(++)$ & 1 \\
\hline 5 & $\mathrm{Si}, \mathrm{Mn}, \mathrm{Fe}(++)$ & 1 \\
\hline 6 & $\mathrm{Si}, \mathrm{Ti}, \mathrm{Fe}(++)$ & 2 \\
\hline 7 & $\mathrm{Si}, \mathrm{Al}, \mathrm{S}(++)$ & 1 \\
\hline 8 & $\mathrm{Al}, \mathrm{Ti}, \mathrm{Fe}(++)$ & 1 \\
\hline 9 & $\mathrm{Ti}, \mathrm{Mn}, \mathrm{Fe}(++)$ & 2 \\
\hline 10 & Si, Ti, Mn, Fe(t+) & 5 \\
\hline 11 & $\mathrm{Si}, \mathrm{Al}, \mathrm{Mn}, \mathrm{Fe}(++)$ & 1 \\
\hline 12 & $\mathrm{Si}, \mathrm{Al}, \mathrm{Ti}, \mathrm{Fe}(++)$ & 1 \\
\hline 13 & $\mathrm{Al}, \mathrm{Ti}, \mathrm{Mn}, \mathrm{Fe}(++)$ & 2 \\
\hline 14 & $\mathrm{Ca}, \mathrm{Ti}(++), \mathrm{Mn}, \mathrm{Fe}(++)$ & 1 \\
\hline 15 & $\mathrm{Si}, \mathrm{Al}, \mathrm{Ti}, \mathrm{Mn}, \mathrm{Fe}(++)$ & 3 \\
\hline 16 & $\mathrm{Si}, \mathrm{S}(++), \mathrm{Ti}(+), \mathrm{Cr}, \mathrm{Fe}$ & 1 \\
\hline 17 & $\mathrm{Si}, \mathrm{Ca}, \mathrm{Ti}, \mathrm{Mn}, \mathrm{Fe}(++)$ & 1 \\
\hline 18 & $\mathrm{Si}, \mathrm{Al}, \mathrm{Cl}, \mathrm{Mn}, \mathrm{Fe}(++), \mathrm{Ti}$ & 1 \\
\hline 19 & $\mathrm{Si}, \mathrm{Al}, \mathrm{Ca}, \mathrm{Ti}(++), \mathrm{Mn}, \mathrm{Fe}(++)$ & 1 \\
\hline 20 & $\mathrm{Si}, \mathrm{Al}, \mathrm{Mg}, \mathrm{Ti}(++), \mathrm{Ca}, \mathrm{K}, \mathrm{Mn}, \mathrm{Fe}(++)$ & 1 \\
\hline 21 & $\mathrm{Si}(++), \mathrm{Mg}, \mathrm{Al}, \mathrm{Ca}, \mathrm{Ti}(++), \mathrm{Mn}, \mathrm{Fe}$ & 1 \\
\hline
\end{tabular}

$(++)$ indicates the major signal. For types 19 and $21 \mathrm{Ti}$ signal $>\mathrm{Fe}$.

\section{References}

Bhandari N, Arnold J R and Parkin D W 1968 J. Geophys. Res. 731837

Bhandari N, Nijampurkar V N and Shukla P N 1982 Curr. Sci. 51416

Blanchard M B, Brownlee D E, Bunch T E, Hodge P W and Kyte F T 1980 Earth Planet. Sci. Lett. 48178 Dansgaard W 1964 Tellus 16436

Epstein S, Sharp R P and Gow A J 1965 J. Geophys. Res. 701809

King E A and Wagstaff $J 1981$ Antarctic J. 592

Picciotto E, De Maere X and Friedman I 1960 Nature (London) 187857

Sipri Year Books 1968-79 Cumulative index (1980)World armaments and disarmaments (London: Taylor and Francis) p. 90

Wagstaff J and King E A 1981 Lunar Planet. Sci. XII 1124 